\title{
Territorial development through cultural tourism and creative activities
}

Ludovico Solima and Antonio Minguzzi

\section{(2) OpenEdition}

12 Journals

\section{Electronic version}

URL: http://journals.openedition.org/tourisme/366

DOI: $10.4000 /$ tourisme.366

ISSN: 2492-7503

\section{Publisher}

Éditions touristiques européennes

\section{Printed version}

Date of publication: 1 December 2014

Number of pages: 6-16

ISSN: 2109-5671

\section{Electronic reference}

Ludovico Solima and Antonio Minguzzi, « Territorial development through cultural tourism and creative activities », Mondes du Tourisme [Online], 10 | 2014, Online since 30 September 2015, connection on 19 April 2019. URL : http://journals.openedition.org/tourisme/366 ; DOI : 10.4000/ tourisme.366

\section{cc)}

Mondes du tourisme est mis à disposition selon les termes de la licence Creative Commons Attribution - Pas d'Utilisation Commerciale - Pas de Modification 4.0 International. 


\section{Territorial development through cultural tourism and creative activities}

\author{
LUDOVICO SoLIMA \\ Professeur associé en Économie et gestion des entreprises \\ Seconda Università di Napoli (Université de Naples II) \\ [ludovico.solima@unina2.it]
}

\author{
Antonio Minguzzı \\ Professeur associé en Management des \\ destinations • Université du Molise \\ [minguzzi@unimol.it]
}

Résumé. Cet article vise à définir un cadre d'évaluation de la compétitivité des destinations touristiques jouissant d'un solide patrimoine culturel (tangible ou intangible) et ayant retenu des modèles de développement centrés sur les industries culturelles et créatives locales. À partir d'une solide analyse de la littérature scientifique, tant italienne qu'internationale, sur les destinations touristiques à fort patrimoine culturel, il évalue l'impact des industries créatives sur le développement régional. Le modèle ainsi établi constituera un outil au service de l'élaboration de politiques de gestion coordonnées et globales des destinations touristiques créatives. Cette recherche a également pour ambition de grossir la littérature sur la gestion des destinations car, si ce fonds est fourni au niveau international, il est relativement pauvre en études approfondies sur le patrimoine culturel et sur les liens entre industries culturelles et créatives, d'une part, et processus de développement local, d'autre part. Ainsi, bien que s'appuyant sur des travaux apportant un accroissement marginal de la connaissance, cette recherche vise à établir un cadre très novateur. Une fois les résultats escomptés obtenus, ce cadre non seulement contribuera au débat scientifique, mais accompagnera aussi les politiques des destination touristiques.

Abstract. The aim of this paper is to identify an interpretative framework for the competitiveness of tourism destinations defined by a strong tangible or intangible cultural heritage and which have identified development patterns focused around local cultural and creative industries. This paper will analyse in depth both Italian and international literature on tourist destinations with a strong cultural heritage, evaluating the implications of creative industries for regional development. The resulting model will help to develop a coordinated and comprehensive management policy for creative tourism destinations. This research aims at contributing to the literature on destination management, which, whilst extensive at an international level, is relatively scarce for in-depth studies on cultural heritage and the relationship between cultural and creative industries and local development processes. For these reasons, although the approach to this work can only be based upon marginal increases in knowledge, it aims at setting out a new and highly innovative framework. Achieving the desired results will contribute not only to the scientific debate on the subject, but also support regional development initiatives as defined by tourist destination policies. 


\section{DETERMINING FACTORS IN THE ANALYSIS MODEL}

\section{Tourism and destination management}

The debate on tourism has always been based upon the presumption of a link between social and economic activities and their territory of reference, while simultaneously identifying all the relative resources. The process of identifying tourist resources underpins the conditions for developing the strategies and organisation for a tourism system (Grant, 1994; Teece, Pisano and Shuen, 1997). It is therefore necessary to appreciate and organise the various components of the natural and the built environment (mountains, churches, castles, monuments and so on), together with the set of immaterial resources, such as local culture or brands and even human resources, in order to have a complete picture of all the tourist resources within a given local system. The debate surrounding the development of social and economic tourist activities is therefore based above all upon analysing a territory, understood as "the set of material and immaterial values, such as people, culture, historical legacy, urban and artistic heritage, infrastructures, localisation and any other type of situation that can increase the value of the single parts" (Kotler, Haider and Rein, 1993, p. 93).

The second fundamental conceptual step is where applying economic management models to a tourist destination results in a "place" being defined as a "product". The tourist destination acquires its own overall identity, and can therefore follow the same strategic management methods adopted in the business sector.

It follows that territories, especially tourist destinations, are required to act competitively with the aim of implementing strategies that will differentiate them from other areas with which they are in competition, and produce wealth and value for the players in their own territorial system by increasing tourists and visitors. A more comprehensive and contemporary definition of the competitive success of a destination is "a destination's capacity of increasing the well-being of its residents through tourism. The actual success of the destination is measured by the contribution that tourism makes towards enhancing the sustainable well-being of destination's residents" (Ritchie and Crouch, 2003, p. 142).

While a destination's competitivity depends upon its wealth of tangible (and intangible) resources, its progress is linked to its capacity of adopting management policies that recognise the relationships established between the players who make up the system in its entirety (Minguzzi and Presenza, 2010).

It follows that the success and complexity of a tourist destination are determined, on the one hand, by the structural components of the territory and, on the other, by how they interact to create value, progress and well-being for the different players within the touristic and territorial system (Minguzzi, 2006).

\section{The cultural sector}

A territory can be analysed through in a number of different keys, emphasising certain aspects, in particular those concerning the economic fabric and the demographic structure of the territory, or its natural, landscape-based and cultural resources. If these are intrinsically consistent resources, in both quantitative and qualitative terms, this naturally influences the local development processes, where they can help to achieve competitive goals, such as economic growth, social well-being, etc.

In this context, interest tends to focus initially on cultural aspects, which are then analysed from a tourism point of view, in order to identify an attraction factor that will help the development process of a destination (Prentice, 1993; Timothy and Boyd, 2006).

Proceeding along these lines, it is necessary first to establish the cultural boundaries under the understanding that the sector has been interpreted according to different models, which, over the years, have progressively expanded its scope.

First and foremost, a distinction can be made between tangible cultural assets and intangible cultural assets, where the former relate, according to all available evidence, to the physical evidence of man's work, such as monuments, archaeological sites, museums and works of art belonging to permanent collections, etc., while the latter consist of the activity, practice and knowledge surrounding a community defined by 
TAble 1 • The Sectors Of CULtUral and Creative Industries

\begin{tabular}{|c|c|c|c|}
\hline CIRCLES & SECTORS & SUB-SECTORS & CHARACTERISTICS \\
\hline \multirow[b]{3}{*}{ 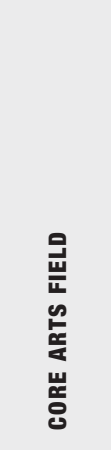 } & Visual arts & $\begin{array}{l}\text { Crafts } \\
\text { Paintings - Sculpture - } \\
\text { Photography }\end{array}$ & \multirow{3}{*}{$\begin{array}{l}\text { - Non industrial activities. } \\
\text { - Outputs are prototypes and "potentially } \\
\text { copyrighted works" (i.e. these works } \\
\text { have a high density of creation that would } \\
\text { be eligible to copyright but they are } \\
\text { however not systematically copyrighted, } \\
\text { as it is the case for most craft works, } \\
\text { some performing arts productions } \\
\text { and visual arts, etc.). }\end{array}$} \\
\hline & Performing arts & $\begin{array}{l}\text { Theatre - Dance - } \\
\text { Circus - Festivals }\end{array}$ & \\
\hline & Heritage & $\begin{array}{l}\text { Museums - Libraries - } \\
\text { Archaeological sites - } \\
\text { Archives }\end{array}$ & \\
\hline \multirow{4}{*}{ 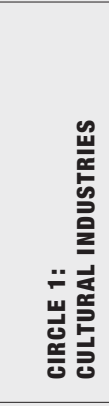 } & Film and Video & & \multirow{3}{*}{$\begin{array}{l}\text { - Industrial activities aimed at massive } \\
\text { reproduction. }\end{array}$} \\
\hline & $\begin{array}{l}\text { Television } \\
\text { and radio }\end{array}$ & & \\
\hline & Video games & & \\
\hline & Music & $\begin{array}{l}\text { Recorded music market - } \\
\text { Live music performances - } \\
\text { revenues of collecting } \\
\text { societies in the music sector }\end{array}$ & \multirow[t]{2}{*}{ - Outputs are based on copyright. } \\
\hline & Books and press & $\begin{array}{l}\text { Book publishing - } \\
\text { Magazine and press publishing }\end{array}$ & \\
\hline \multirow{3}{*}{ 总 } & Design & $\begin{array}{l}\text { Fashion design, graphic } \\
\text { design, interior design, } \\
\text { product design }\end{array}$ & \multirow{3}{*}{$\begin{array}{l}\text { - Activities are not necessarily industrial, } \\
\text { and may be prototypes. } \\
\text { - Although outputs are based on copyright, } \\
\text { they may include other intellectual property } \\
\text { inputs (trademark for instance). } \\
\text { - The use of creativity (creative skills and } \\
\text { creative people originating in the arts field } \\
\text { and in the field of cultural industries) is } \\
\text { essential to the performances of these } \\
\text { non-cultural sectors. }\end{array}$} \\
\hline & Architecture & & \\
\hline & Advertising & & \\
\hline 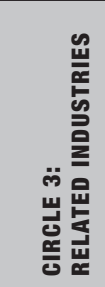 & $\begin{array}{l}\text { PC manufacturers, } \\
\text { MP3 player } \\
\text { manufacturers, mobile } \\
\text { industry, etc. }\end{array}$ & & $\begin{array}{l}\text { - This category is loose and impossible to } \\
\text { circumscribe on the basis of clear criteria. } \\
\text { It involves many other economic sectors } \\
\text { that are dependent on the previous } \\
\text { "circles", such as the ICT sector. }\end{array}$ \\
\hline
\end{tabular}

"the cultural sector"

"the creative sector" 
its strongly identifying link with history and local traditions.

The link between cultural heritage and tourism can depend upon a number of tourist services involved in the many processes to maximise this heritage, which vary according to the different decisions that tourists take about which destination they choose and how best to enjoy it. Before visiting a destination, their decisions are made through information, booking and purchasing systems; during their visit, through tourist welcome services and other services aimed at making their experience a memorable one; on their return, through initiatives with the aim of reinforcing loyalty to the destination.

This increasing integration of the tourism offer is counterbalanced by the simultaneous and progressive affirmation of a specific type of tourist demand, cultural tourism. In this case, accessing the tangible and intangible cultural heritage of a territory is the only, or at least the principle, reason that visitors choose the destination in the first place and then enjoy what it can offer ${ }^{(1)}$.

\section{Creative industries}

The cultural sector's importance does not only depend upon its intersection with a substantial portion of the tourism market, because, as shown in the most recent literature, there is another, and possibly even more extensive interconnection with the so-called creative "industries"(2), leading to the so-called "creative tourism" (Richards, 20I I; Flew and Cunningham, 2010).
As recently highlighted by Santagata (2009), both tangible and intangible historical and artistic heritage represents the expression of human creativity, both past and present. Therefore, architecture, contemporary art and performance art (music and entertainment) can also be included within the definition of cultural and artistic heritage.

The different ways to express a territory's culture represent the methods by which creativity is seeded, to become available for other creative bursts (Pratt, 2013). Creativity is also the raw material of the socalled "content industries" (publishing, radio, television, advertising and cinema) $)^{(3)}$. Further sectors that benefit from the cultural dimension of a territory are those that fall within the scope of "immaterial culture" (fashion, design and crafts, gastronomy, computer technology).

A further framework, which does not necessarily coincide with the one just analysed, is contained in the report prepared by Kern European Affairs (KEA, 2006) for the Directorate-General for Education and Culture of the European Commission, and proposes a concentric model. This includes a first nucleus of activity, Core Arts Fields, containing cultural heritage and visual and performing arts, and a secondary sphere, Cultural Industries, containing publishing, musical, audio-visual and video games. The former involves a consumer end-product that cannot be reproduced and is intended for local consumption (a concert, an exhibi- tion, etc.). The latter refers to industrial sectors where the consumer end-product can be reproduced (books, films, recordings) and is intended for mass production, disconnected from any geographic context.

Finally, within this model, and which will be covered in greater depth later on, there is a more external group, that of "Creative Industries and Activities", which includes sectors not generally referred to as cultural, such as design, architecture and advertising, but which are classified in this way as work in this areas makes an overriding use of creative professional capacities. Culture therefore becomes a "creative" input to realise non-cultural assets $^{(4)}(c f$. table 1$)$. On the basis of this interpretation, the action of companies operating in creative sectors is intrinsically linked to the existence of the cultural assets and activities within a specific geographical area ${ }^{(5)}$.

It is clear that, in terms of local development, the cultural assets of a territory can be analysed by looking at the role that they have within the tourist sector and how they relate to the operators of content creation and transmission and those involved in the production of assets and services connected to creativity ${ }^{(6)}$ (Campbell, 201 I).

Table 2 highlights the relative importance of the creative industries in the world economy. It shows the significant growth rates that are produced both in developed economies than in emerging ones in the past decade. 
Table 2 • Creative goods: exports, by economic Group, 2002 and 2008 (In millons of \$)

\begin{tabular}{|c|c|c|c|c|c|c|c|c|}
\hline & \multicolumn{2}{|c|}{ World } & \multicolumn{2}{|c|}{ Developed economies } & \multicolumn{2}{|c|}{ Developing economies } & \multicolumn{2}{|c|}{$\begin{array}{l}\text { Transition } \\
\text { economies }\end{array}$} \\
\hline & 2002 & 2008 & 2002 & 2008 & 2002 & 2008 & 2002 & 2008 \\
\hline All Creative Industries & 204.949 & 406.992 & 127.903 & 227.103 & 75.836 & 176.210 & 1.210 & 3.678 \\
\hline Art Crafts & 17.503 & 32.323 & 8.256 & 11.443 & 9.202 & 20.715 & 45 & 164 \\
\hline Audiovisuals & 462 & 811 & 425 & 726 & 35 & 75 & 3 & 10 \\
\hline Design & 114.692 & 241.972 & 60.967 & 117.816 & 53.362 & 122.439 & 362 & 1.716 \\
\hline New Media & 17.365 & 27.754 & 11.422 & 13.248 & 5.908 & 14.423 & 36 & 82 \\
\hline Performing Arts & 9.689 & 26.136 & 8.947 & 22.539 & 698 & 3.323 & 43 & 274 \\
\hline Publishing & 29.817 & 48.266 & 25.970 & 38.753 & 3.157 & 8.138 & 690 & 1.376 \\
\hline Visual Arts & $|5.42|$ & 29.730 & 11.916 & 22.578 & 3.474 & 7.097 & 31 & 56 \\
\hline
\end{tabular}

Source: UNCTAD, 2010.

\section{Graphic 1 • Cultural production sector multipler \\ (EUROS ACTIVATED FOR EACH EURO GENERATED IN CULTURAL PRODUCTION SECTOR)}

Cultural industries

Cultural heritage

Performing arts

and entertainment

Over all cultural production sector

Source: Unioncamere and Fondazione Symbola, 2013.
1,2

2

\section{Methodology}

Paper's methodology is based on the validation of mechanisms of territorial development by analysis of economic data of cultural tourism and creative industries.

As mentioned in the literature (Yin, 2003) the analysis of the single "case study" may be sufficient to identify phenomena "drive specific" related to the critical factors that influence local patterns of development.

The analysis of the relationship between culture, creativity and local development is built on industry data for Europe and Italy. The relationship confirms the critical factors paths of cultural-led local development. The results are discussed with reference to the European industry conditions considering the specific implications of the Italian economy.

\section{The ITALIAN CASE}

As recently registered by the Osservatorio Nazionale del Turismo, in the first six months of 2011, just under $40 \%$ of visiting Italians (equal to 15.6 million people) chose destinations of historical and artistic value as their travel destination, an increment of one percentage point compared to the previous year ${ }^{(7)}$. Over the same period, visits to state-owned 
places of culture increased by nearly $10 \%$ compared to the previous year, with around 20 million visitors ${ }^{(8)}$.

In relation to the creative industries, Italy confirms its leading economy in the value of transactions even if development rates were less intense of its world competitors ( $c f$. table 3).

Qualitative analysis of the cultural offer carried out recently on Bank of Italy and Urban Audit data showed a stable trend or a slight deterioration in the rating of foreign tourists satisfaction compared to five Italian cities between 2006 and 2012 (cf. table 4). In this empirical analysis have been evaluate the opinions of the tourists on the services and factors that influence the experience and perception of cultural tourism in the city sample. The results show in detail the characteristics of the foreign consumer of Italian "cultural" industry and use it as a driver of interpretation of the phenomenon.

On the basis of the foregoing emerges an important reflection to be developed in relation to the theoretical approaches. The international debate is mainly based on AngloSaxon models providing a whole series of ideas on studies into the classification of tourism resources and facilities. At the same time, within the ongoing scientific debate on defining the elements of a territory to be included in the strategic analysis of a tourist destination's development, it is fully acknowledged that there is a well-defined connection to the system of cultural wealth of both tangible and intangible heritage
(Simeon and Martone, 20 I4).

The approach of the studies on cultural and creative industries with the implications of tourism specialization provides a first response to the industry level on the basis of the empirical analysis related to the evaluation of the economic effects of their development in terms of fallout on the overall economy of the country.

The graphic 1 highlights a strong multiplier effect on the development of the cultural system on the Italian economy.

The next step is working on the recent literature on cultural and creative industries onto two theoretical bodies (i.e. the management of the destination and its cultural heritage and initiatives) to create an integrated framework having as a common denominator the studies on local development issues (Flew, 2013).

\section{COMPLEXITY, DIRECT AND INDIRECT RELATIONSHIPS}

On the basis of what has been stated so far, it is possible to identify a relationship between cultural heritage and the tourist sector in terms of local development, relative to the economic side-effects generated by flows of visitors who remain, for a more or less time, in a certain territory.

Economic side-effects are measured by evaluating their economic impact, which frequently takes place when there is public investment in culture. As mentioned previously, in this case there seems to be a need to tap the economic aspects associated to public financial flows set up to support the investment processes within the cultural sector that are capable of generating economic value in direct, indirect and induced terms (Solima, 1999, 2006).

In terms of generating economic value directly, it should be noted that cultural heritage's contribution towards a growth in local economy is based upon a number of assets and services directly linked to its very existence. The preparation of a catalogue for a museum, a radio transmission on the occasion of a musical performance or a television programme at the inauguration of an art exhibition determine, at least potentially, the creation of economic value within the territory ${ }^{(9)}$.

The capacity of a territory to attract tourist flows is part of its overall indirect impact, which takes into account what tourists spend in buying goods (such as typical local products) and hospitality services (from restaurants, hotels and similar) in the territory being analysed.

In terms of induced economic value, we mean the buying capacity set in place locally through the processes of wealth generation referred to above, which set off a train of further consumption at local level, evaluated by using a correlation coefficient to multiply the expen$\operatorname{diture}^{(10)}$.

By introducing cultural and creative industries at this point in the thinking process, it is evident that the territory can be further enhanced by its capacity of fuelling creative circuits, through its material or immaterial cultural capital, which is the raw material of highly intensive 
Table 3 • Creative economy: leading trade in Europe

\begin{tabular}{|c|c|c|c|c|c|}
\hline $\begin{array}{l}\text { EU exports of creative products } \\
\text { increased } 43 \% \text { over } 1996-2005\end{array}$ & \multicolumn{5}{|c|}{$\begin{array}{l}\text { Creative goods: } \\
\text { Top } 10 \text { exporters among developed economies, } 2005\end{array}$} \\
\hline \multirow{3}{*}{$\begin{array}{l}\text { In } 2005 \text {, EU (27) led world exports of } \\
\text { creative goods - US\$ I } 45 \text { billion }\end{array}$} & Rank & $\begin{array}{l}\text { Developed } \\
\text { economy }\end{array}$ & $\begin{array}{c}\text { Value } \\
\text { (in millions of \$) }\end{array}$ & $\begin{array}{c}\text { Market } \\
\text { share (\%) }\end{array}$ & $\begin{array}{l}\text { Growth } \\
\text { rate }(\%)\end{array}$ \\
\hline & & & 2005 & 2005 & $2000-2005$ \\
\hline & 1 & Italy & 28.008 & 8,35 & 5,9 \\
\hline \multirow[t]{2}{*}{ Italy strong position in design } & 2 & United States & 25.544 & 7,61 & 3,6 \\
\hline & 3 & Germany & 24.763 & 7,38 & 14,2 \\
\hline Creative services rising sharply II\% & 4 & United Kingdom & 19.030 & 5,67 & 9,8 \\
\hline annual growth 2000-2005 (advertising, & 5 & France & 17.706 & 5,28 & 8,6 \\
\hline \multirow[t]{2}{*}{ architecture, digital, R\&D) } & 6 & Canada & I I.377 & 3,39 & 1,7 \\
\hline & 7 & Belgium & 9.343 & 2,78 & - \\
\hline Developed countries accounted for $82 \%$ & 8 & Spain & 9.138 & 2,72 & 8,1 \\
\hline \multirow[t]{2}{*}{ of world services exports } & 9 & Netherlands & 7.250 & 2,16 & 9,7 \\
\hline & 10 & Switzerland & 6.053 & 1,8 & 9,1 \\
\hline
\end{tabular}

Source: Staines and Mercer, 2013.

Table 4 • Rating Of Foreign TOURISTS SATISFACTION FOR FIVE ITALIAN CITIES, 2006-2012

\begin{tabular}{l|c|c}
\hline & \multicolumn{2}{c}{ Foreign tourist } \\
\hline & rank 2006 & rank 2012 \\
\hline Bologna & 3 & 2 \\
Napoli & 4 & 4 \\
Palermo & 5 & 5 \\
Torino & I & 3 \\
Verona & 2 & I \\
\hline
\end{tabular}

Note: $1-2=$ high; $3=$ medium; $4-5=$ low. productive processes (Lazzaretti and Cinti, 2009).

As underlined in Florida's seminar paper (2002), creative people and resources are strongly linked to their context and therefore difficult to replicate $^{(11)}$. For this reason, territory plays a crucial role, in the extent to which it can exalt the territorial aspects of the local human capital, stimulating the creation and development of creative industries ${ }^{(12)}$.

This means that the concept of intangible capital can be reached from another angle. This concept has directed the blossoming Italian literature on the origins and development of Italian districts (Becattini, 2000). In other words, human and social capital are not only important for the contribution they can bring to the local production fabric (in terms of qualified workers and knowledge seeded in the people living there), but rather for a different type of contribution that they bring to an innovative production process based upon talent and creativity.

This circumstance makes it possible to reinterpret the traditional approaches to destination management in a critical way, and on a wider scale, be capable of analysing, and appreciating, the contribution offered by other economic operators outside the tourist chain, but still influenced by the tangible and intangible cultural capital of the territory ${ }^{(13)}$.

The same strategic option used to maximise complementary elements in a logic of reciprocal inte- 
gration between the economic operators of the territory - a lever increasingly used by local policy makersmust be framed into a new, wider perspective that takes into account the additional levels of interconnection with the local entrepreneurship ${ }^{(14)}$ (García-Tabuenca, Crespo-Espert and Cuadrado-Roura, 20 II).

We will therefore configure our model to analyse territorial competitiveness according to three main axes. The first is composed of the tangible and intangible attractions within the territory, possibly at a local level; the second is represented by the set of existing structures and infrastructures that support and make the best use of tourism; the third, covering cultural and creative industries, promotes the potential for innovative development within the territory, through what is called creative tourism.

As previously mentioned, in this paper we wish to focus on the wealth of tangible and intangible cultural heritage in a specific territory, given the levels of interconnection with the operators of local entrepreneurship previously described. When proposing our model of analysis, we decided that it could be useful to include other strongly contextual resources that could form a system of "attractions within the territory", which is one of the three sustaining axes of the theoretical formulation under discussion.

The system of attractions within a territory, combined with the material and immaterial cultural heritage, refers to natural resources, habitat

\section{Figure $1 \bullet$}

THE COMPETITIVE Factors IN THE EXPANDED MODEL FOR LOCAL DEVELOPMENT

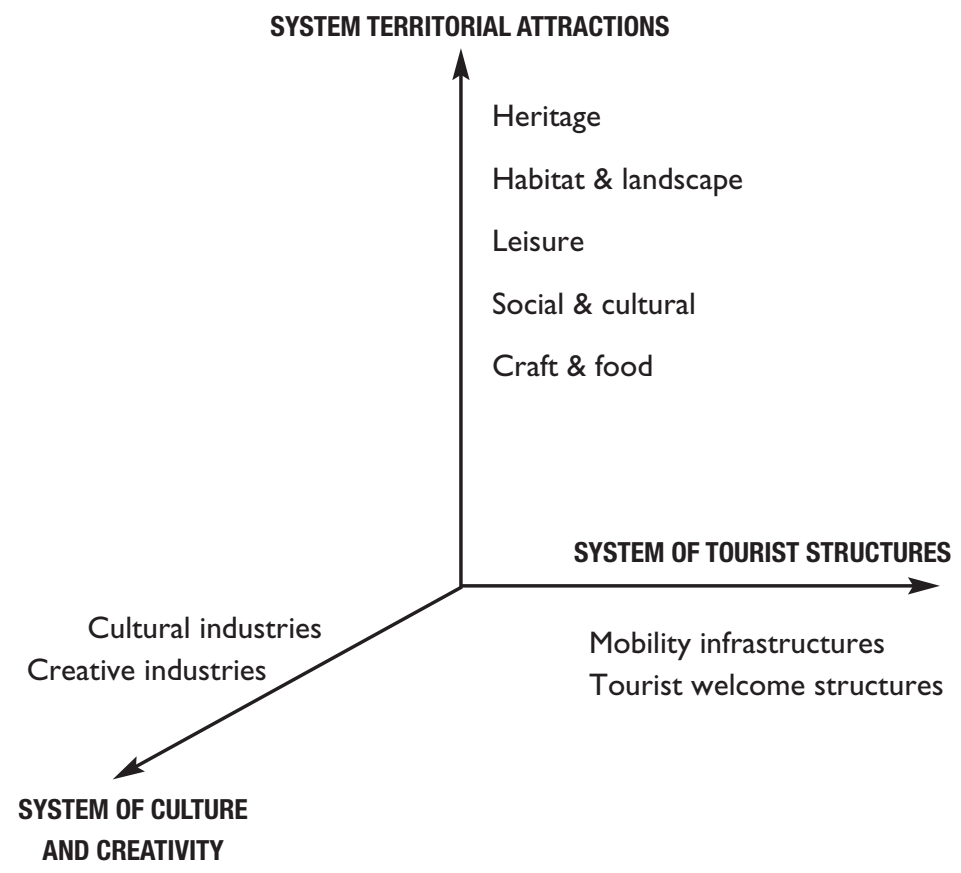

and landscape resources; leisure resources, such as golf courses, theme parks, clubs, etc.; social and cultural resources, such as events and shows, and also artistic and cultural activities; assets and services linked to typical local crafts and foods, such as food and wine, and artistic crafts.

The second axis of the model is represented by the system of touristic facilities, which include infrastructures supporting mobility (tourist arrival points, facilities and services for transport by air, sea, rail and road, etc.) and hospitality-related facilities (welcome desks, restaurants and catering services, etc.). A further key element for the competitiveness of a destination is defined by these structures and the quality of the services they provide.
The third axis is composed of the system of cultural and creative industries that include, for the former, broadcasting operators (videos, films, television, music) and publishing, and, for the latter, operators working in design, architecture and advertising. The figure 1 summarises what has been said up until now.

\section{WORKING CONDITIONS AND POLICY THEORY}

The issues discussed and proposed in the previous chapter modify the picture of destination management in the way it is structured in current literature (Ritchie and Crouch, 2003; Minguzzi and Presenza, 2010). This change occurs through an increased complexity, producing an effect both on governance and the strategic fra- 
mework (Andres and Chapain, 20 I3). The number of reference variables is increased, and there is a greater complexity within the system of relationships, producing direct and indirect effects on the tourist destination's territorial and production systems (Comunian, Chapain and Clifton, 20 I0).

The approach specifically relating to creative tourism destination management, represented by a driver for overall destination complexity obtained by co-ordinating tangible and intangible resources within a common governance (Minguzzi, 2006) is combined to the complex theme of cultural heritage, which, in Italy, is both a factor underpinning tourism and promoting its growth, and, at the same time, a sector often governed by a conservative and self-defining logic rather than with the aim of achieving the most benefit and implementing a system-based view.

In this context, the understanding of the role of creative industries, as defined previously, assumes a particular significance for its direct and indirect links to the tourist-cultural system (Minguzzi, Paniccia and Valeri, 201 I; Pilotti, 201 I).

Creative industries are in turn defined by intangible components (local identity, history, tradition), which are structured over time into a series of products and services that become part of the economic actions taking place both in the investment process and in that of selling the end product. This highlights the ties between creativity and the creation of factors of attraction within the destination. One only needs to think about the wine and food related issues that strongly define Italy as a whole, and in particular those products that have become international, such as pizza. In a similar way, local traditions and the specific history of a territory have determined manifestations that have become extremely popular international events (the Palio of Siena, to give one example). We could also look at artistic events offering popular music, and a number of literary, theatrical, cinematographic and television festivals, which can be local events, as well as production companies and locations that can influence the creative tourism system economically in varying degrees, through the movement of people, capital and profit.

No less important are advertising initiatives, which are based on creativity and are used by operators to represent the tourist system and spread knowledge about it to the outside world. In a wider perspective, the entire cultural heritage system is in turn the historical expression of a creative and architectural creativity belonging to cultures that existed in these territories in times preceding the present one.

A strong interrelation emerges between the three axes of the model, where the variables are integrated within a relationship of reciprocal functionality. Creativity, in its widest meaning, creates the conditions and stimulates the development of many elements of attraction in the territory that produce value for visitors (tourists) and local residents, through the very existence of a system of tou- rist structures and infrastructures and the way it operates.

\section{CONCLUSIONS AND IMPLICATIONS}

The basic idea is that it is not enough to identify a single major strategy for a territory's economic and social growth from among those on offer in order to integrate the various players operating within the tourism and cultural supply chains of the territory. And further, the viewpoint must be expanded to incorporate within the local development process those operators who make use, directly or indirectly, of a territory's cultural heritage. This occurs directly for "cultural industries", which promote cultural heritage, and indirectly for "creative industries", whose innovation processes are fuelled by creativity within the social fabric and are, in turn, influenced-in a very decisive way-by the very presence of a cultural heritage and associated initiatives, leading to a new form of tourism, creative one (Zhang and Wang, 2010).

The proposed model of analysis reveals how creative tourism systems are becoming increasingly more complex to manage when they are seen as systems in competition with other territorial systems (Fernandes, 20 I I). If creative industries are inserted into this approach, it is possible to highlight both the growing importance of intangible resources as determining factors within the processes of competitivity, and the bonds that influence or favour the development of the system.

In particular, issues regarding the sustainability of creativity within a 
system cannot be separated from the role of education, which is not always integrated with the players and the dynamics of the territory to which it refers, although it is always a critical factor for the territory's economic and competitive development (Minguzzi and Presenza, 2012). Regarding tourist competitivity, the operational implications deduced from our analysis should be split into two. The first part relates to the tourism-territorial system, and the second to the businesses composing it.

For the former, we must analyse the true governance conditions defining Italy at this particular moment in time. For around ten years (see the legislation on tourism, Law $n^{\circ}$ $135 / 2001$ ), the legislator has set out the coordination procedures that must exist between the responsibility for tourist organisation issues given by law to the regions, and the necessary central coordination process carried out through local tourism systems (LTS), which every region must set up within its territory. To date, this model of intervention has been shown to be non-systematic, as it is difficult to implement either in the regions where there was already a well-established tourist organisation system or in those where a lack of consolidated experience or a lack of political will has meant that it could not be fully implemented. Also to date, about half the Italian regions have adopted LTSs that are themselves beset with teething problems under the arduous governance models to be implemented in order to manage situations bursting with pro- tagonists, administrative complexities that need coordinating, strategic conflicts with other specialisations within the territory and, not least, a lack of community identity among the operators.

Closing the gap between tourism and the system of cultural heritage has been, for some time, an important issue of debate, and one not yet been fully achieved, mainly because of the different historical and administrative background separating the two systems. The culture of "conservation" that has rightly defined the cultural heritage system since it came under public administration has resulted in its autonomous and separate management through bodies known as superintendencies, which cannot now be integrated into the governance of local tourism systems despite the great progress and growth of a culture exalting cultural heritage.

It is therefore not easy to think about rapidly expanding tools of intervention for creative tourismrelated policies specifically for creative industries (Zhang, 20I3). The mechanisms whereby creative industries have an indirect influence over the tourism system and the already critical role of the education system are such that it is difficult to anticipate how these aspects can be coordinated within regional tourism legislations within a short time.

Regarding companies, operational development could have different dynamics. According to both the classic strategic view of optimisation limited by a company's objectives in terms of the competitive structure of the market in which it operates (Porter, 1980), and the resource-based view (Grant, 1994), the role of creative industries in creative tourism systems could determine a growing “dematerialisation" of the various factors of competitivity.

The role of creativity in businesses (DCMS, 1998; European Commission, 2010) and in territorial systems (Foord, 2008; Santagata, 2009) implies that a company must understand how much weight the two components have on its present and future competitiveness. This obviously depends on the business model and the structure of the internal value chain, with different dynamic balances being involved over time.

At an operative level, a company's strategy must concentrate on the importance of creativity for its business models with great accuracy and define how much creativity weighs on its operations compared to how deeply it is embedded within the territory, representing therefore a comparative advantage relative to its competitors located elsewhere.

Only by evaluating very clearly the weight of this intangible factor within a company's dynamic strategy will it be possible to make the successful step of transferring knowledge into best practice.

\section{NOTES}

(I) In literature and in practise, and specifically in the case of national and international research institutes preparing cultural statistics, the identification of cultural tourism is 
somewhat inconsistent (Garrod and Fyall, 200 I). Approaches based on the reasons leading to selecting a specific destination are those that seem highly likely to supply the most correct interpretation (Nyaupane, White and Budruk, 2006), particularly when compared to those that reclassify touris demand according to the destination's (cultural) wealth, which, especially in Italy, is often drawn up by local administrations and is not necessarily objective.

(2) The first definition of creative industries can be traced back to the report prepared by the English Government Department for Culture, Media and Sport (DCMS) at the end of the last century [https://www.gov.uk/govern ment/publications/creative-industries-mappingdocuments-1998].

(3) On this subject, it should be stated that content industries made their first appearance with the refinement of printing technology (Gutenberg's invention of mobile characters and printing press in the mid-15th century), so that, for the first time, "multiples" could be produced at a low cost, intended for a progressively wider public compared to the privileged classes that up until then had been the exclusive keepers of knowledge (and the power they derived from it). In more recent times, digitalisation of contents has provided a further boost to the circulation of information, progressively emphasising the role of distribution (Solima, 2004, chap. I).

(4) "Culture is not analysed as a source of final consumption (as in the case of films, books, music, cultural tounism, etc.) but as a source of intermediate consumption in the production process, most of the time the final products being functional (to the contrany of works of arts or to the output of cultural industries) (...) Multiple examples can be given to illustrate the economic added-value of creativity and of its cultural components: design is the perfect example. It is an activity involving the use of cultural references and education for the production of non-cultural goods and services" (KEA, 2006, pp. 36-38).

(5) This approach, in its conception, is similar to Marshall's idea of "industrial atmosphere", that is, the existence of a heritage of various skills spread within a specific territory, capable of assisting the generation and development of district-based activities.

(6) "Many recent studies have shown that the cultural and creative industries (hereafter, "CCls") represent highly innovative companies with a great economic potential and are one of Europe's most dynamic sectors, contributing around $2.6 \%$ to the EU GDP, with a high growth potential, and providing quality jobs to around 5 million people across EU-27. (...) Beyond their direct contribution to GDP, CCls are also important drivers of economic and social innovation in many other sectors" (European Commission, 2010, pp. 2-3).

(7) Osservatorio Nazionale del Turismo, II turismo culturale in Italia, November 20 I | [http://www.ontit.it/opencms/opencms/ont/it/f ocus/focus/ll_turismo_culturale_in_italia].

(8) MIBAC, "Statistiche Culturali" [http://mww.statistica.beniculturali.it].

(9) This occurs, naturally, to the extent in which the economic operators are located in the same territory of a cultural heritage. If the catalogue of an exhibition taking place in Salemo is produced in Milan, obviously the flow of wealth is located outside the territorial boundaries (typically of a municipality or region) that had been identified for the impact assessment.

(I0) In particular, refer to Bowitz and lbenholt (2009), Choi, Ritchie, Papandrea and Bennett (20I0), and to the references quoted by them.

( I I) Florida, as has been correctly highlighted, "says that creative firms will increasingly follow the talent (which he labels 'the creative class') because creative people look for cultural amenities and because creative people and resources are more difficult to replicate. In other words, the spatial dimension and the interactions generated on a limited territory are crucial for creativity to emerge and contribute to the economy. A virtuous circle can then be nurtured, because these creative people, once concentrated on a territory, will create synergies and fruitful collaborations, thereby fostering further creativity" (KEA, 2006, p. 39),

(I2) Although there may seem to be a paradox, the globalisation of economic processes does result in specific territorial aspects being preferred over others, imposing a new competitive approach in which the factor "local", virtuously combining global and local aspects, becomes a defining element in the success of a territory.

(13) With reference to cultural districts, Trimarchi (2009) effectively underlines the relationship between culture and creativity. In Italy, this can be expressed in various ways: "Industrial districts of culture, or creative districts, can be considered as the backbone of Italian creativity, and include productions such as opera in Emilia-Romagna (homeland to Verdi and Toscanini and host to a network of very active opera theatres); music in Naples (ranging from the nineteenth century melodies to the more recent world music and contemporary opera by De Simone); industrial design and fashion design in Milan; cinema, media and audio-visuals in Rome; and handicrafts and food and wine in various regions" (Trimarchi, 2009, p. 235).

(14) In the approach adopted here, we intend to expand the observation perspective, identifying the territory as a unit of analysis from a social angle that does not necessarily coincide with that of metropolitan cities (Barcelona, Berlin, London, etc.), which is the one generally considered in studies on creative clusters (Foord, 2008). 


\section{DOSSIER • TOURISME CRÉATIF}

\section{Références bibliographiques}

Lauren ANDRES and Caroline CHAPAIN, "The integration of cultural and creative industries into local and regional development strategies in Birmingham and Marseille: towards an inclusive and collaborative governance?", Regional Studies, vol. 47, n’. 2 ("Understanding Creative Regions"), 2013.

Giacomo BECATTINI, II distretto industriale.

Un nuovo modo di interpretare il cambiamento economico,

Rosenberg \& Sellier, 2000.

Einar BOWITZ and Karin IBENHOLT, "Economic impacts of cultural heritage. Research and perspectives", Journal of Cultural Heritage, vol. 10, n. I, 2009.

Peter CAMPBELL, "Creative industries in a European capital of culture", Intemational Joumal of Cultural Policy, vol. 17, n'. 5, 2011.

Andy S. Chol, Brent W. RitCHIE, Franco PaPANDREA and Jeff BENNETT, "Economic valuation of cultural heritage sites: a choice modelling approach", Tourism Management, vol. $31, n^{\circ} .2,2010$.

\section{Roberta Comunian, Caroline ChaPAIN and Nick Clifton,}

"Location, location, location: exploring the complex relationship between creative industries and place", Creative Industries Joumal, vol. 3, no. I, 2010

DCMs, The Creative Industries Mapping Document,

DCMS, 1998

European Commission, Green Paper of 27 April 2010

Unlocking the Potential of Cultural and Creative

Industries, 2010 [http://europa.eu/legislation_summaries/culture/cu0006_en.htm].

Carlos Fernandes, "Cultural planning and creative tourism in an emerging tourist destination", Intemational Journal of Management Cases, vol. 13, n॰ 3 ("CIRCLE Conference"), 20I I.

Terry FleW and Stuart CUNNINGHAM, "Creative industries after the first decade of debate", The Information Society: An International Joumal, vol. 26, n'. 2 ("Creative Industries and Urban Development"), 2010
Terry FLEW (ed.), Creative Industries and Urban Development: Creative Cities in the 21st Century, Routledge, 2013.

Richard L. FLORIDA, The Rise of the Creative Class: And How it's Transforming Work, Leisure, Community and Everyday Life, Perseus Books Group, 2002.

Jo FOORD, "Strategies for creative industries: an international review", Creative Industries Joumal, vol. I, no. 2, 2008.

Antonio García-TABUenCA, José Luis Crespo-ESPERT and Juan R. CUADRADO-RouRA, "Entrepreneurship, creative industries and regional dynamics in Spain", The Annals of Regional Science, vol. 47, n. 3, 201 I.

Brian GARROD and Alan FyalL, "Heritage tourism: a question of definition", Annals of Tourism Research, vol. 28, n. 4, 200 I. Robert M. GRANT, L'analisi strategica nella gestione aziendale, I Mulino, 1994 (original edn Contemporary Strategy Analysis, Blackwell, 1991).

KEA, The Economy of Culture in Europe, study prepared for the European Commission, October 2006

[http://ec.europa.eu/culture/library/studies/culturaleconomy_en.pdf].

\section{Philip KotLer, Donald HaIDER and Irving ReIN, Marketing}

Places: Attracting Investment, Industry, and Tourism to Cities, States, and Nations, Free Press, 1993.

\section{Luciana LAZZARETTI and Tommaso CINTI,}

"Governance-specific factors and cultural clusters: the case of the museum clusters in Florence", Creative Industries Joumal, vol. 2, n'. I, 2009

Antonio MINGUZZI, "Network activity as critical factor in development of regional tourism organization. An Italian case study", in Luciana LazZARETtI and Clara S. Petrillo (eds), Tourism Local Systems and Networking, Elsevier, 2006.

Antonio MinguzZI, Paola PanicCIA and Marco ValerI, "Coevoluzione tra impresa e destinazione turistica. L'esperienza innovativa dell'albergo diffuso", in Luciano Pilotti (ed.), Creatività, innovazione, territorio. Ecosistemi del valore per la competizione globale, II Mulino, 20I I. 
Antonio MinguzZI and Angelo PresenZA, Destination building. Teorie e pratiche per il management della destinazione turistica, Pearson Prentice Hall, 2010.

Antonio MinguzZI and Angelo PresenZA, "Le condizioni di efficacia nel processo di sviluppo turistico di un territorio", in Monica Meini (ed.), Turismo al plurale. una lettura integrata del territorio per un'offerta turistica sostenibile, FrancoAngeli, 2012.

\section{Gyan P. NyauPANE, Dave D. WHITE and Megha BudRUK,}

"Motive-based tourist market segmentation: an application to Native American cultural heritage sites in Arizona, USA", Journal of Heritage Tourism, vol. I, n. 2, 2006.

Luciano PILOTTI (ED.), Creatività, innovazione e territorio. Ecosistemi del valore per la competizione globale, II Mulino, 2011.

Michael E. PORTER, Competitive Strategy, Free Press, 1980. ANDY PRATT, "The cultural and creative industries: new engines for the city?", in Wilfried Wang (ed.), Culture: City, Lars Müller, 2013.

Richard PRENTICE, Tourism and Heritage Attractions,

Routledge, 1993.

Greg Richards, "Creativity and tourism: the state of the art", Annals of Tourism Research, vol. 38, no. 4, 201 I.

J. R. Brent RitCHIE, Geoffrey I. Crouch, The Competitive Destination. A Sustainable Tourism Perspective,

CABI Publishing, 2003.

Walter SANTAGATA (ED.), Libro bianco sulla creatività,

EGEA, 2009.

Maria I. SIMEON and Assunta MARTONE, "Relationships between Heritage, intangible capital and cultural and creative industries in Italy: a framework analysis for urban regeneration and territorial development", Advanced Engineering Forum, vol. II, 2014.

Ludovico Solima, "L'impatto economico dei musei: l'esperienza del Guggenheim Museum di Bilbao", Economia della Cultura, no. 2, 1999.

Ludovico Solima, L'impresa culturale. Processi e strumenti di gestione, Carocci, 2004.
Ludovico Solima (ed.), Rapporto sull'economia dei beni culturali in Campania, Mondadori Electa, 2006.

Judith Staines and Colin Mercer, "Mapping of cultural and creative industry export and internationalisation strategies in EU Member States", in European Expert Network on Culture (EENC) Report, February 2013.

David J. Teece, Gary PIsAno and Amy Shuen, "Dynamic capabilities and strategic management", Strategic Management Joumal, vol. 18, n. 7, 1997.

Dallen J. TIMотнY and Stephen W. BOYD, "Heritage tourism in the 2 Ist century: valued traditions and new perspectives", Joumal of Heritage Tourism, vol. I, n. I, 2006.

Michele TRIMARCHI, "The economics and policy of creativity: the Italian perspective", Creative Industries Journal, vol. 2, n'. 3, 2009

UNCTAD [United Conference on Trade and Development], Creative Economy Report 2010: Creative Economy: A Feasible Development Option, 2010

[http://unctad.org/en/Pages/PublicationArchive.aspx?publicationid=946].

UNIONCAMERE and FONDAZIONE SYMBOLA, lo sono cultura.

L'Italia della qualità e della bellezza sfida la crisi, 2013

[http://www.symbola.net/html/article/losonoculturaLItaliadella qualitaedellabellezzasfidalacrisi].

Robert K. YIN, Case Study Research: Design and Methods ( $3^{\text {rd }}$ edn), Sage, 2003 ( I $^{\text {st }}$ edn 1984).

Hai-yan ZHANG and Zhong-yun WANG, "Research on industrial convergence development of tourism industry and cultural industry", Resource Development \& Market, n. 4, 2010. Yurong ZHANG, "Study on the main characteristics and development countermeasures of creative tourism", 2013 International Conference on Education, Management and Social Science, ICEMSS 2013, August 2013. 